\title{
ФЕНОМЕН САМОПРИЙНЯТТЯ ТА ЙОГО ПРОЯВИ: КОНТЕНТ-АНАЛІЗ TBOPIB-CAMO3BITIB
}

\author{
Ірина Гордіснко \\ аспірантка кафедри загальної та диференціальної психології \\ Державний заклад «Південноукраїнський національний педагогічний \\ університет імені К. Д. Ушинського» \\ 65020, Україна, м. Одеса, вул. Старопортофранківська, 26 \\ 2sanak@gmail.com, https://orcid.org/0000-0001-7089-2698
}

\begin{abstract}
Анотація
У статті викладаються результати дослідження широкого спектру прояву феномену самоприйняття як багаторівневої властивості особистості, що відбиває специфіку та ступінь прийняття людиною себе такою, якою вона $є$. Мета дослідження - вивчення якісних характеристик самоприйняття, які надають змогу отримати уявлення про його модальність (якість та знак - прийняття чи неприйняття себе) та ознаки в контексті основних видів психічної активності людини: емоційної, когнітивної та поведінкової. Теоретико-методологічною основою дослідження обрано континуально-ієрархічну концепцію структури особистості, запропоновану О. Санніковою, в межах якої презентовано якісні характеристики самоприйняття. Основним методом дослідження визначено контент-аналіз творів-самозвітів. Предметом дослідження виступили індикатори якісних характеристик самоприйняття. Процедура контент-аналізу творів за темою «Самоприйняття та його прояви» проводилась у три етапи: підготовчий, виконавчий та аналітико-інтерпретаційний. За результатами аналізу було визначено 274 лінгвістичні одиниці, що надають додаткову інформацію про психологічний зміст та структуру феномену самоприйняття особистості, було складено тезауруси якісних показників самоприйняття, що об'єднані у відповідні блоки, які характеризують емоційний, когнітивний, поведінковий i контрольно-регулятивний компоненти самоприйняття. До емоційного блоку увійшли характеристики емоційно-забарвленого переживання самоприйняття щодо визнання свого існування таким, яким воно $\epsilon$. Індикатори когнітивного параметру самоприйняття - континуум ознак, які відбивають згоду людини 3 існуванням такою, яка вона $\epsilon$, в думках. Індикатори поведінкового параметру надано діапазоном ознак зовнішніх проявів у поведінці, діях, що відбивають самоприйняття або неприйняття себе. Контрольно-регулятивний параметр презентовано ознаками, які відбивають ступінь контролю за емоційною, когнітивною, поведінковою репрезентаціями прийняття себе та мірою самоусвідомлення, що забезпечує стійкість самоприйняття на відповідному, індивідуально прийнятому рівні. За результатами контент-аналізу визначено риси особистості, що гіпотетично пов'язані з самоприйняттям як властивістю особистості, та чинники самоприйняття.
\end{abstract}

Ключові слова: самоприйняття, структура самоприйняття, твори-самозвіти, контентаналіз, якісні характеристики самоприйняття.

\section{Вступ}

Дослідження будь-якого психологічного феномену, його концептуалізація, передбачає ретельне вивчення змістовного наповнення, функцій, структури, особливостей 
прояву в усіх сферах психічної активності людини. Напрямами цього дослідження є теоретико-методологічний аналіз феномену у сучасних $\mathrm{i}$ класичних наукових дослідженнях, пошук споріднених понять у просторі психічних явищ, здійснення емпіричного дослідження взаємозв'язку феномена, що вивчається, 3 широким колом психологічних рис, процесів i станів особистості, звертання до досвіду самоспостереження і самоаналізу індивідів, узагальнення та систематизація набутої інформації.

Одним з таких методів $є$ аналіз творів-самозвітів. Метод самозвіту - словесний або письмовий звіт про результати самоспостережень, опис людиною своїх вчинків, переживань про феномен, що досліджується (Н. Костенко \& В. Іванов, 2003). Контентаналіз творів виявляє частоту використання різних смислових одиниць (наприклад, певних понять, суджень, образів, характеристик емоційного ставлення тощо). Поряд 3 недоліками даного методу, до яких відносять суб'єктивність респондентів у поглядах на феномен та можливостях його визначення (що зумовлено індивідуальною здатністю до самоаналізу, особливостями рефлексивності та широтою власного тезауруса щодо визначення та опису думок, емоційних станів, переживань, поведінки тощо), контентаналіз самозвітів має свої незаперечливі переваги. Серед них особливо слід визначити змогу дослідника отримати інформацію, так зване, мовою самого суб'єкта, щодо констатації безпосереднього досвіду переживання особистістю-респондентом широкого спектру прояву феномену, на який спрямована увага у дослідженні. За допомогою якіснокількісного аналізу творів, тобто контент-аналізу, на відміну від застосування психодіагностичних методик високого рівня формалізації, вдається подолати суб'єктивність дослідника у визначені феномену та його характеристик (Гуревич \& Борисова, 1997). Автори творів-самозвітів, завдяки умовам безоціночного ставлення та конфіденційності, які забезпечуються дослідником, мають можливість висловлювати свої погляди, описувати реальні переживання та внутрішні мотиви вчинків у життєвих ситуаціях, що надає цим творам характер максимальної щирості та автентичності.

Мета дослідження: локус уваги було зосереджено на самоприйнятті як багаторівневої властивості особистості, що відбиває специфіку емоційно-забарвленого ставлення індивіда до себе та характеризує ступінь прийняття людиною себе такою, якою вона $\epsilon$, незалежно від оцінки своїх переваг і недоліків (Саннікова \& Гордієнко, 2018). Метою дослідження стало вивчення якісних характеристик самоприйняття, оскільки саме вони надають змогу отримати уявлення про його модальність (якість та знак - прийняття чи неприйняття себе) та ознаки в контексті основних видів психічної активності людини, а саме: емоційної, когнітивної та поведінкової (Саннікова \& Гордієнко, 2018). Завдання дослідження: 1) на засадах теоретичного аналізу структури феномена самоприйняття розробити процедуру емпіричного дослідження змісту його структурних компонентів; 2) визначити та впровадити етапи контент-аналізу творів-самозвітів як методу збору інформації та дослідження широкого спектру прояву феномену самоприйняття як властивості особистості в межах його якісних структурних показників; 3) за результатами дослідження скласти змістовну характеристику якісних показників самоприйняття.

\section{Методи дослідження}

У дослідженні було застосовано наступні методи:

- теоретичний аналіз досліджень з проблеми самоставлення як властивості особистості щодо визначення якісних показників у структурі даного феномена;

- метод контент-аналізу творів-самозвітів. 
Нами було проведено теоретичний аналіз досліджень 3 проблеми самоставлення особистості, який дозволив виявити, що більшість дослідників термін «самоприйняття» розуміють як безумовно позитивне ставлення до себе, що виявляється в довірі та відкритості до всього спектру своїх переживань (думок, почуттів, відчуттів) і щирості в їх прояві (Маслоу, 2001; Пантилеев, 1991; Роджерс, 2001; Фромм, 2007; Herbert, Forman \& England, 2009; Williams \& Lynn, 2010). Разом з тим, в психології існує велика кількість іноді недостатньо чітко виокремлених термінів, що позначають простір синонімічних понять даного аспекту самосвідомості. До них можна віднести такі психічні явища, як аутосимпатія, безумовне позитивне ставлення до себе, емоційне ставлення до себе, емоційний компонент самооцінки, любов до себе, прийняття себе, самоакцептація, самоприяття, самоповага, самосхвалення, самоцінність, що було презентовано в роботах Р. Бернса, Д. Гошовської, А. Елліса, С. Колкової, I. Кона, М. Лісіної, В. Майструк, А. Маслоу, С. Пантилєєва, К. Роджерса, I. Сарджвеладзе, О. Соколової, В. Століна, Е. Фромма та ін. (Саннікова \& Гордієнко, 2018). Неоднозначність у трактуванні феномена «самоприйняття» зумовлена його складністю, різними методологічними позиціями дослідників, що призводить до суперечливості у визначенні. Вивчення самоприйняття залишає без уваги структурний аналіз цього складного утворення особистості, що потребує ретельного дослідження його компонентів і показників. Тому, поряд 3 традиційним методом теоретико-методологічного аналізу феномену самоставлення у наукових дослідженнях, нами було здійснено контент-аналіз творів-самозвітів за темою «Самоприйняття та його прояви». В цьому дослідженні був застосований нестандартизований твір-самозвіт, в якому інформація певною мірою конкретизується (наратив) у вигляді завдань-питань, відповідаючи на які досліджуваний міг повною мірою презентувати специфіку індивідуального прояву самоприйняття та самоставлення. Наратив, з позиції Н. Чепелєвої, «...організує, структурує та артикулює життєвий досвід людини» (Чепелєва, 2013: 4).

У даному дослідженні ми спирались на роботи В. Нєбиліцина, в яких активність в емоційній, інтелектуальній та руховій сфері розглянуто як основні види психічної активності людини (Небылицин, 1976). Також опорою нашого дослідження обрано континуально-ієрархічну концепцію структури особистості, запропоновану О. Санніковою (Санникова, 2007; Саннікова, 2013), в межах якої макроструктура самоприйняття як властивості особистості може бути представлена за трьома рівнями: формально-динамічним, змістовним i соціально-імперативним, кожен 3 яких характеризується своїм специфічним змістом. Зона перетину формально-динамічного (перший рівень) і змістовно-особистісного (другий) рівнів - підструктура якісних характеристик самоприйняття, які містять інформацію про його модальність (якість та знак - прийняття чи неприйняття себе) та ознаки основних видів психічної активності людини, а саме: емоційні, когнітивні, конативні (поведінкові) та контрольно-регулятивні показники самоприйняття.

У процедурі складання творів-самозвітів, яка проводилося на базі Державного закладу «Південноукраїнський національний університет імені К. Ушинського» та Одеського національного політехнічного університету, взяли участь 90 осіб - студенти, які набувають освіту за спеціальностями «психологія», «соціальна робота», «культурологія», «менеджмент» денної та дистанційної форм навчання віком від 19 до 39 років. Основними вимогами до учасників дослідження були визначені: бажання прийняти участь у дослідженні; достатній рівень рефлексії; щирість і вміння письмово викладати матеріал (Гуревич \& Борисова, 1997). Метою дослідження стало вивчення якісних 
характеристик самоприйняття методом контент-аналізу творів самозвітів, предметом індикатори якісних характеристик самоприйняття.

Процедура контент-аналізу творів за темою «Самоприйняття та його прояви» проводилась у три етапи:

1. Підготовчий етап. На цьому етапі було визначено мету та предмет дослідження, розроблено процедуру дослідження, складено класифікатор (опорна схема для контентаналізу) та завдання-питання, підготовлено інструкції для осіб, які беруть участь у реалізації методу, здійснено пілотажне дослідження.

2. Виконавчий етап, протягом якого здійснювалась процедура складання творівсамозвітів.

3. Етап частотного аналізу, інтерпретації та узагальнення результатів. На цьому етапі було проведено якісний та кількісний аналіз характеристик самоприйняття за визначеними критеріями (блоками та індикаторами). До таких блоків аналізу було віднесено: «авторське» визначення феномену самоприйняття задля можливості виявлення опорних елементів; прояв самоприйняття у емоційній, когнітивній та поведінковій сферах; визначення властивостей, які притаманні особистості, що приймає себе, та особистості, що не приймає себе; умови та чинники самоприйняття. Оскільки досліджувались якісні показники самоприйняття, які належать суміжній зоні між формально-динамічним та змістово-особистісним рівнями макроструктури самоприйняття (Саннікова, 2013), пошук цих характеристик здійснювався у просторі саме психологічних рис особистості. При цьому властивості самоприйняття особистості формально-динамічного рівня та змістового порядку (особистісні властивості - за Б. Ананьєвим; підструктура спрямованості - за К. Платоновим; властивості змістово-особистісного рівня за континуально-ієрархічної структури особистості (Саннікова, 2013) спеціально у даному дослідженні не розглядалися. Цей етап закінчувався складанням тезаурусу характеристик, проявів розробленої системи показників схильності до самоприйняття. Конкретно були складені тезауруси якісних показників самоприйняття, що об'єднані у відповідні блоки, які характеризують емоційний, когнітивний, поведінковий i контрольно-регулятивний компоненти самоприйняття.

Оскільки використання творів-самозвітів як метод дослідження має своїм недоліком низький рівень формалізації завдань та матеріалу аналізу (Костенко \& Іванов, 2003), ми запропонували досліджуваним певні питання, які надали змогу спрямувати та конкретизувати відповіді та розкрити психологічний зміст феномену самоприйняття. До питань, що визначили структуру творів-самозвітів увійшли:

1. «Прийняття себе, з моєї точки зору - це ...?».

2. «Як проявляється у Вас переживання прийняття себе (надайте характеристику емоційним переживанням, думкам, поведінковим проявам)?».

3. «Як Ви переживаєте неприйняття себе (емоційні переживання, думки, поведінкові прояви)?».

4. «За якими ознаками Ви впізнаєте, приймає себе чи ні, інша людина?».

5. «Що, на Ваш погляд, ускладнює самоприйняття?», «Що допомагає Вам прийняти себе?». 


\section{Результати та дискусії}

За результатами аналізу було визначено 274 лінгвістичні одиниці, що надають додаткову інформацію про психологічний зміст та структуру феномену самоприйняття особистості. Наведемо далі результати первинного, кількісного аналізу частоти прояву певних характеристик у творах-самозвітах (у дужках за кожною ознакою вказана частота iii поширення у текстах, численні одноразові випадки означень не наведено).

I. Так у «авторському» визначені феномену самоприйняття найбільш поширеними варіантами відповідей виявлено: «любити себе таким, який є» (29), «бути собою» (28), «любити, приймати себе $з$ усіма недоліками та особливостями» (23), «приймати себе таким як є, незалежно від оцінки, яку надаєш собі, своїм вчинкам та проявам» (22), «адекватно сприймати себе, свої переваги та недоліки» (20), «поважати себе (17)», «бути таким, як є» (12), «задоволеність собою, своєю зовнішністю, своїми вчинками, своїм характером» (10), «усвідомлювати свої сильні та слабкі сторони» (10), «приймати свої недоліки та опрацьовувати їх» (8), «приймати свій вибір» (7), «розуміти себе» (7), «не комплексувати» (7), «бачити в собі унікальність, особливість» (7), «не соромитися своїх недоліків» (6), «бути в гармонії з самим собою (6), з тілом та душею (2)», «дивиться на себе без самозвинувачення (5), докору (5), дорікань(4)», «згода зі своїм внутрішнім голосом, орієнтація на себе» (4), «надавати собі право бути собою, право на власні вчинки» (4), «цінувати всі свої риси та якості» (3), «відчувати себе вільним, незалежним від думки та оцінки інших» (3), «бути чутливим до себе» (2).

II. Відповіді досліджуваних на друге та третє запитання: «Як проявляється у Вас переживання прийняття себе (надайте характеристику емоційним переживанням, думкам, поведінковим проявам)?», надало змогу виявити характерні прояви самоприйняття у емоційній, когнітивній та поведінкових сферах. Крім того, змістовний аналіз наданих характеристик дозволив виявити додатковий аспект прояву самоприйняття - контрольнорегулятивний - який не було запропоновано до уваги опитуваних. Наведемо зміст кожного з означених якісних блоків опису самоприйняття.

1. Емоційне переживання самоприйняття. Надані характеристики розподіляються на дві групи за позитивним та негативним модусом ставлення до себе, тобто емоційні прояви прийняття або неприйняття себе. Позитивний полюс емоційного переживання самоприйняття, за результатами частотного аналізу, склали ознаки: відчуття поваги до себе (25); задоволеність собою (25); почуття любові до себе (21); комфортне почуття себе (21); перебування у гарному настрої, життерадісність (20); душевний спокій (20); відчуття симпатії до себе (20); задоволення своєю зовнішністю (18); почуття себе впевнено (8); почуття себе вільно (4); відчуття себе щасливою людиною (3); задоволення від відчуття себе унікальною, «особливою» людиною (3); задоволення від того, що відбувається навколо (3); не боїться бути смішним, недоречним (3); не боїться помилитися (3); любить та з задоволенням, без сорому приймає похвалу (2); почуття себе стійко (2); почуття себе у безпеці, не бачить загрози з боку оточуючих (2).

Негативний полюс емоційного переживання самоприйняття проявляється як: відчуття страху, тривоги (21); дратівливість, напруженість, знервованість (20); страх бути відторгненим (19), бути покинутим (18); відчуття себе відторгненим (17); стурбованість тим як він виглядає (17); постійне відчуття провини та сорому (15); часте відчуття провини за зроблене (13); часте відчуття незадоволеності собою (12); боязнь щодо 
критики (9); інтенсивна потреба у схваленні (9); страх помилитися (8); страх бути засудженим (8); страх проявити себе (8); сором'язливість (7); ворожість (7), агресивність (7); відчуття заздрощі до інших, які впевнені у собі (6); надмірно емоційна, хвороблива реакція на критику (6); розчарованість щодо себе (5); страх визнавати свої певні якості (5); незадоволеність оточуючими людьми та навколишнім світом (5); ненависть, непримиримість до своїх недоліків (5); відчуття себе безпорадним (5); пригніченість (4); озлобленість (4); емоційна залежність від значущої людини, власний емоційний стан залежить від емоційного стану та ставлення оточуючих (3); боязнь саморозкриття (3); боязнь проявляти ініціативу (3); скептичне ставлення до інших, ставлення з недовірою (3); імпульсивність, дратливість, неврівноваженість (3); страх змін (3); відчуття труднощів, неможливості щодо прояву своїх почуттів (2); відчуття збентеження та недовіру, коли його схвалюють (2).

2. Когнітивні ознаки переживання самоприйняття також представлено двома полюсами - позитивно та негативно забарвленими думками, судженнями щодо себе, своїх особливостей, визнання самого факту свого існування. Позитивний полюс когнітивного аспекту самоприйняття за результатами частотного аналізу склали ознаки: позитивні думки щодо себе, наприклад: «Я - гідна людина», «Я - існую і це - добре» (22); усвідомлення як своїх сильних, так й своїх слабких сторін особистості (21); аналіз всього спектру своїх думок та ідей, які усвідомлюються (18); впевненість у своїх думках, ідеях (17); незалежність від думок інших (9); є стійке, сформоване уявлення щодо своєї особистості (7); не порівнює себе з іншими (5); інтерес щодо себе (5) та до навколишнього світу (3); власний світогляд (4); визнання своїх недоліків як своєї особливості (3).

Ознаки негативного полюсу когнітивного аспекту прийняття себе: орієнтація на думку інших (25); опора на думку інших щодо себе, а не на власну (12); постійне відчуття сумнівів щодо своїх думок, дій (10); визнання тільки своїх недоліків, «зацикленість» на них (8); невпевненість у своїх думках, позиціях (7); визнання себе нікчемою (7); неприділення уваги та неврахування власних бажань, потреб (5); думки відносно себе як людини недоречної, нікчемної, невдахи (5); неспроможність адекватно себе оцінити (5); відчуття труднощів щодо визнання своїх недоліків (4); завищенні очікування (4); думки відносно себе як людини, яка гірша (дурніша, огидніша) за інших (4); негнучкість у своїх поглядах (4); негативне сприйняття себе, або, взагалі, свого існування у світі, наприклад, «Краще було б, якби я був би іншим», «Краще було б, якби я не існував би» (3); необ'єктивність (3); вважає сарказмом комплементи інших (2); відсутність інтересу до життя (2); надмірна різкість та критичність (2).

3. До поведінкових проявів позитивного полюсу самоставлення, тобто самоприйняття, опитувані віднесли: щире висловлювання своєї думки (25); доброзичливе ставлення до інших (21); відкрите висловлювання своєї позиції, своїх почуттів, думок та поглядів (17); вміння визнавати свої помилки (9); доречне, аргументоване відстоювання своєї точки зору, без загроз та принижування партнера (9); не дорікання собі (8), незвинувачування себе (8); ненав' язування своєї думки іншим (8); конструктивну реакцію на критику (8); впевнена поведінка у стосунках, у спілкуванні (7); активна та ініціативна поведінка (5); не критикує себе (5); спілкування «на рівних», не принижуючи інших (5); позитивне та яскраве почуття гумору (4); відкрите визнання, що подобається собі (4); не критикує інших (3); багато й приємно посміхається (3); вміння користатися своїми 
особистісними ресурсами (3); активне самопізнання (3); гідну поведінку у незручних обставинах (2); «говорить про свої успіхи без надмірної сором’язливості» (2).

Згідно відповідей опитуваних, людина, яка не приймає себе, у поведінці виявляє: закритість, замкнутість (21); орієнтованість на інтереси інших людей більше, ніж на власні (18); скутість (17); невпевнену поведінку (15); підлаштовується під інших (14); часто звинувачує себе за зроблене (12); занадто критикує себе (12); забагато часу приділяє самовдосконаленню (10); критикує інших (8); постійно намагається щось зміни у собі або в оточуючих (7); відстороненість - віддаляється від інших, «сидить на самоті», (6); звинувачує інших або ситуацію (5); здійснює самопошкодження, «селфхарм» (5); не приймає компліменти, вважає це сарказмом (4); приділяє багато зусиль, щоб сподобатись іншим (4); агресивна поведінка, не враховуючи ситуації (4); часто порівнює себе з іншими (4); у міжособистісних стосунках принижує себе, каже: «Я не достойний іiі / Я не достойна його» (3); конфліктне поводження у стосунках (3); надмірно збентежена, метушлива (3); демонструє надмірну різкість у стосунках (3); ««заїдає» / «запалює» / «запиває» стрес і тривогу або, навпаки, немає апетиту» (3); мовчазність, «з нього й слова не витягнеш», (2); сам себе обмежує у стосунках (2); надмірно експериментує зі своєю зовнішністю, стилем (2); виконує прохання інших, коли не хоче, але тому що не може сказати «Ні» (2)»; у поведінці намагається бути непомітним, немов хотів би сховатися від усіх (2).

4. Контрольно-регулятивний блок склали характеристики: постійне порівняння себе 3 іншими (15); «постійно оцінює та контролює те, як він виглядає» (12); стурбованість думкою інших щодо себе (9); старання у прагненні «довести себе до ідеалу» (5); «занадто багато аналізує свою поведінку» (8); заперечення у собі негативних, на власний погляд, якостей (8); перебування у фантазіях, побудова ідеальних моделей, яких слід дотримуватися (5); уникнення ситуацій, де $є$ ризик саморозкриття (4); надмірний контроль над своїми діями та проявами (3); намагання всім сподобатися (3); «носить «маску»» (3); відмова від власних поглядів, якщо вони не підтримуються оточуючими (2); самозмінення з метою самовдосконалення, але не з метою саморозвитку (2); обмеження себе в активності зі страху помилитися (2); допомога іншим досягнути гармонії із собою (2); відчуття спокою, «в собі нічого не бентежить» (3). Всі наведені характеристики, окрім відчуття спокою, «у собі нічого не бентежить», характеризують, згідно відповідей, стан людини, яка не приймає себе.

III. Аналіз творів-самозвітів надав змогу скласти переліки рис, що належать особистості, яка приймає себе, та особистості, якій притаманне самонеприйняття. Рисами особистості, яка приймає себе, є: впевненість у собі (68); адекватна самооцінка (64); «любов до себе» (60); позитивне ставлення до себе, незважаючи на певні свої риси та особливості (60); позитивне ставлення до оточуючих (51); відкритість, щирість, нелицемірство (40); привабливість (19); товариськість (17); саморозуміння (17); довіра до себе (16); самоповага (16); віра в себе (15); знаходиться у гармонії із собою (13) та світом (4); незалежність, самодостатність (12); стійкий, високий рівень самовладання (11); прийняття інших (10); впевненість щодо своїх рішень (10); адекватне сприйняття ситуації (10); адекватне сприйняття критики (10); комунікабельність (10); розкутість (9); відкритість до власного внутрішнього світу (8); «з ним хочеться спілкуватися» (8); цілеспрямованість, зосередженість (7); трохи завищена самооцінка (7); немає схильності до змін (7); «3 ним легко, приємно спілкуватися» (6); людина, яка активна та ініціативна у 
стосунках, діяльності (5); визнає світ у всьому різноманітті (4); «не намагається здаватися краще, ніж є» (4); щасливий (3); «відкритість до нового» (3); інтерес та готовність до самопізнання та пізнання світу (3); «людина, яка реалізує себе, порівнюючи можливості та рівень досягнень» (3); «адекватно відстоює власну точку зору» (3); вміння перебувати «тут і зараз», відчуваючи задоволення від того, що відбувається зараз (3); «людина, яка приймає себе такою, яка є, та рухається вперед, розвивається» (2); готовність до змін та ризику (2); «хочеться йти за ним» (2); «грає за своїми правилами» (2), відчуває себе «особливою», «унікальною людиною» (2); не жалкує про зроблене (2); вірна своїм принципам (2); знає свої ресурси і користується ними (4); стійкість до критики та негативу (4); вміння визнавати свої помилки (2); прислухається до себе (3); має віру у свої можливості (3); терпимість до своїх внутрішніх протиріч (2); терпимість до інаковості іншої людини (2).

До рис, які характерні особистості 3 високим рівнем неприйняття себе, за результатами частотного аналізу, відносяться: занижена самооцінка (58); невпевненість у собі (52); замкнутість (42); прагне отримати схвалення від інших (23); неповага до себе як особистості (19); орієнтація на думку інших людей стосовно себе, опора на думку інших (19); закомплексованість (14); часто сумнівається, вагається (13); пристосування до думки та вимог інших (13); намагається бути ідеальним, але визнає, що для нього це неможливо (12); прагнення бути схожим на когось зразкового, ідеального (на його погляд), наслідувати йому (11); стурбованість думкою інших (9); дратливість (9); приховування своїх емоцій (9); уникає розкриватися перед іншими (9); тривожність (8); нещирість (8); заперечення негативних якостей, які йому притаманні (8); схильність брати на себе всю провину (8); захопленість бажанням все в собі змінити (7); принижує себе (7); занадто суворо ставиться до себе та/або до оточуючих (6); звертає увагу тільки на свої недоліки (6); схильність до заздрості (6); нерішучість (5); недовіряє собі (5); намагається бути кращім для інших (5); чіпляється до своєї зовнішності (5); часто впадає у відчай (4); скучний, не викликає інтересу (4); не довіряє іншим (4); відсутність інтересу до життя (до свого діла, стосунків, успіху та саморозвитку) (4); не любить своє тіло (4); не цікавиться собою (4); багато хвилюються відносно думки про нього з боку оточуючих (4); вже давно шукає себе, та й досі не може знайти (4); надмірно сором'язливий (3); демонструє завищені очікування щодо себе та оточуючих (3); безініціативний (3); уразливий (3); носить «маску» (3); нездатний посміятися над собою (3); шаблонні, стереотипні судження та дії (2); уникає відповідальності (2).

IV. Визначено джерела та ресурси прийняття себе особистістю, серед яких найбільшу визначність серед опитуваних отримали: стосунки з батьками, особливо у дитинстві, їх схвалення та прийняття (18); підтримка близьких людей (18); доброзичливе ставлення з боку оточуючих (15); повага інших (14); успіхи та досягнення (10); власна орієнтація на самоприйняття (6); саморозвиток (4); можливість змінити себе так, як тобі потрібно (4); позитивні стосунки (3); погляд інших людей (3); спрямованість на найкраще (2); доброзичливі стосунки у школі (2); духовний розвиток (2); стійкість внутрішнього «Я»(2).

До джерел і чинників самонеприйняття учасники процедури контент-аналізу творів-самозвітів, окрім вище перелічених інвертованих позицій, віднесли: соціальний тиск, стандарти краси (16); досвід відкидання (10); занижена або неадекватна самооцінка 
(10), невпевненість у собі (9); досвід приниження (8); критику з боку інших (7); осуд і докори з боку близьких (7); стереотипи (6); порівняння себе 3 іншими (5); досвід осміювання, «...так звані «дитячі травми»» (4); зовнішні обставини (бідність, хвороби, недоліки / дефекти зовнішності) (4); глузування і злі жарти (3); надмірну прискіпливість до себе, зайву самокритичність (3); нереалістичні фантазії, яким складно відповідати, внаслідок чого виникає розчарування у собі (3); прагнення до ідеалу, бажання бути найкращим, що ускладнює прийняття своїх недоліків (3); недовіра (2); вузькість мислення (2); відсутність інтересів, поглинання побутом, рутиною (2). Особливо слід відмітити високу частоту вказування на відкидання 3 боку близьких та оточуючих (48), знецінювання (40), брак любові, уваги та піклування у родині (39) як чинники неприйняття людиною самої себе.

Аналіз наданих опитуваними чинників самоприйняття дає змогу поділити їх на дві групи - зовнішні та внутрішні. До зовнішніх чинників відносяться умови взаємодії 3 батьками, 3 близьким середовищем, оточуючими, а до внутрішніх, тобто саме психологічних чинників - сукупність переживань, уявлень, почуттів особистості, що складають специфічну систему самоставлення. Крім того, можна виявити відсутність чіткого визначення причинно-наслідкового зв'язку, а навіть й протиріччя в уявленні опитуваних самоприйняття та його чинників (наприклад, самооцінка та самоповага сприймаються i, як джерело, чинник, i, як наслідок певної модальності самоприйняття), що свідчить про складність та неоднозначність у розумінні даного феномену.

\section{Висновки}

1. Проведення процедури контент-аналізу творів за темою «Самоприйняття та його прояви» дозволило: по-перше, визначити певні категорії аналізу самоприйняття (надання «авторського» визначення феномену самоприйняття задля можливості виявлення опорних елементів; прояв самоприйняття у емоційній, когнітивній та поведінковій сферах; визначення властивостей, які притаманні особистості, що приймає себе та особистості, що не приймає себе; умови та чинники самоприйняття); по-друге, провести формалізацію, частотний аналіз та квантифікацію отриманих даних.

2. Змістовний аналіз відповідей дав змогу розширити опис появу та надати більш чітке визначення основним якісним метапараметрам самоприйняття - емоційному, когнітивному, поведінковому і контрольно-регулятивному. Отже, емоційний компонент самоприйняття відповідає широкому спектру переживань в емоційній сфері, які утворюють континуум проявів почуттів у ставленні до себе та розкривають які саме емоції превалюють у індивіда щодо визнання свого існування таким, яким він $\epsilon$ - від невдоволеності, роздратування, ненависті та сорому, до задоволення, радості й любові та від свого існування у світі.

Когнітивний параметр самоприйняття пов'язано 3 тим, як у думках людини визнається згода 3 існуванням такою, яка вона $\epsilon$, як відбивається сприйняття свого існування та визнання його унікальної цінності, ставлення до своїх особливостей i проявів, а також оцінки, характеристики, якими певна людина наділяє досвід свого існування. Континуум когнітивного модусу переживання містить думки, погляди індивіда, що відповідають або повному прийняттю себе, таким як $\epsilon$, або частковому, або неприйняттю себе та, навіть, запереченню певних власних рис та проявів.

Поведінковому параметру у якісній структурі самоприйняття відповідає діапазон зовнішніх проявів у поведінці, діях, що відбивають самоприйняття або неприйняття себе 
індивідом - від автентичності, щирості, відкритості у проявах особистості, врахування своїх почуттів, думок та інтересів у прийнятті рішень до невпевненості, скутості, надмірної самокритики, самозвинувачення та самопокарання, аж до самопошкодження та самогубства.

Самоприйняття як властивість особистості має ознаки усталеності проявів у часі та в широкому спектрі ситуацій. Контрольно-регулятивний параметр, який виявлясться в ступені контролю за емоційною, когнітивною і поведінковою репрезентаціями прийняття себе та мірою самоусвідомлення, забезпечує стійкість самоприйняття на відповідному, індивідуально прийнятому рівні. Континуум контрольно-регулятивного модусу самоприйняття містить ознаки від відкритості всьому спектру своїх переживань, думок, почуттів, до заперечення певних своїх проявів, постійних спроб самовдосконалення, які мають на меті не саморозвиток, а приближення до ідеалу. Високий рівень стурбованості щодо прийняття іншими йа відповідності очікуванням оточуючих, самообмеження та надмірний контроль над своїми діями i проявами свідчать про високий рівень завантаженості, активності контрольно-захисного механізму забезпечення самоприйняття та виступає характеристикою особистості, яка відчуває труднощі у прийнятті себе такою, яка є. Поглиблене вивчення характеристик означених структурних показників самоприйняття надали змогу скласти комплекс діагностичних методик дослідження якісних компонентів самоприйняття (Саннікова \& Гордієнко, 2019).

3. Результати контент-аналізу творів надали змогу визначити риси особистості, що гіпотетично пов'язані з самоприйняттям як властивістю особистості. Визначено джерела та ресурси прийняття себе особистістю, які умовно можна поділити на дві групи зовнішні та внутрішні. До найбільш впливових зовнішніх чинників, на думку опитуваних, відносяться умови взаємодії з батьками, з близьким середовищем, оточуючими, а до внутрішніх, тобто саме психологічних чинників - сукупність переживань, уявлень, почуттів особистості, що складають специфічну систему самоставлення.

Перспектива подальших досліджень полягатиме у вивченні індивідуальнотипологічних проявів самоприйняття, а саме, дослідженні своєрідності самоприйняття у комбінації його якісних характеристик, їх кількісного виразу, ступеня домінування тощо.

\section{Література}

1. Гуревич, К.М., \& Борисова, Е.М. (1997). Психологическая диагностика. Москва: Издво УРАО.

2. Костенко, Н.В., \& Іванов, В.Ф. (2003). Досвід контент-аналізу: Моделі та практики. Київ: Центр вільної преси.

3. Маслоу, А. (2001). Мотивация и личность. Санкт-Петербург: Евразия.

4. Небылицын, В.Д. (1976). Психофизиологические исследования индивидуальных различий. Москва: Наука.

5. Пантилеев, С.Р. (1991). Самоотночение как эмоционально-оценочная система. Москва: Изд-во МГУ.

6. Роджерс, К.Р. (2001). Становление личности. Взгляд на психотерапию. Москва: Издво ЭКСМО-ПРЕСС.

7. Санникова, О.П. (2007). Формально-динамические и качественные метахарактеристики индивидуальности. Наука і освіта. 6-7, 30-33.

8. Саннікова, О.П. (2013). Макроструктура особистості: психологічний опис. Наука $i$ освіта. 7/CXVII,7-12.

9. Саннікова, О.П., \& Гордієнко, І.О. (2018) Психодіагностична методика «індивідуальна композиція показників самоприйняття»: перевірка теоретичного конструкту». Проблеми сучасної психологї: зб. наук. пращь Державного вищого навчального закладу 
«Запорізький нащіональний університет» та Інституту психологї імені $Г$. С. Костюка НАПН України. 1(13), 140-146.

10. Саннікова, О.П., \& Гордієнко, І.О. (2019). А.с. Науково-методичний твір «Комплекс методик діагностики якісних компонентів самоприйняття: «Експрес-діагностика якісних компонентів самоприйняття»; «Індивідуальна композиція якісних показників самоприйняття»») Реєстрац. № 93758 від 07.11.2019.

11. Фромм, Э. (2007). Искусство любить. Санкт-Петербург: ИД «Азбука-классика».

12. Чепелєва, Н.В. (2013). Методи аналізу оповідального тексту. Технологї розвитку інтелекту. 4, 4. http://nbuv.gov.ua/j-pdf/tri 2013 4_4.pdf

13. Herbert, J.D., Forman, E.M., \& England, E.L. (2009) PSYCHOLOGICAL ACCEPTANCE. - General Principles and Empirically Supported Techniques of Cognitive Behavior Therapy/ edited by William O'Donohue, Jane Fisher. (pp. 102-114) URL:https://www.researchgate.net/publication/230745911_Psychological_acceptance

14. Williams, J.C., \& Lynn, S.J. (2010) Acceptance: an historical and conceptual review. Imagination, cognition and personality, 30(1), 5-56. https://doi.org/10.2190/IC.30.1.c

\section{References}

1. Gurevich, K.M., \& Borisova, E.M. (1997). Psihologicheskaja diagnostika [Psychological diagnostics]. Moskva: Izd-vo URAO [in Russian].

2. Kostenko, N.V. \& Ivanov, V.F. (2003). Dosvid kontent-analizu: Modeli ta praktyky [Content-analysis experience: Models and practices]. Kyiv: Tsentr vilnoi presy [in Ukrainian].

3. Maslou, A. (2001). Motivacija i lichnost' [Motivation and personality]. Sankt-Peterburg: Evrazija [in Russian].

4. Nebylicyn, V.D. (1976). Psihofiziologicheskie issledovanija individual'nyh razlichij [Psychophysiological studies of individual differences]. Moskva: Nauka [in Russian].

5. Pantileev, S.R. (1991). Samootnoshenie kak jemocional'no-ocenochnaja sistema [Selfattitude as an emotional-evaluative system]. Moskva: Izd-vo MGU [in Russian].

6. Rodzhers. K.R. (2001). Stanovlenie lichnosti. Vzgljad na psihoterapiju [The formation of personality. A look at psychotherapy]. Moskva: Izd-vo JeKSMO-PRESS [in Russian].

7. Sannikova, O.P. (2007). Formal'no-dinamicheskie i kachestvennye metaharakteristiki individual'nosti [Formal-dynamic and qualitative metacharacteristics of personality]. Nauka $i$ osvita. 6-7, 30-33 [in Russian].

8. Sannikova, O.P. (2013). Makrostruktura osobystosti: psykholohichnyi opys [Macrostructure of personality: psychological description]. Nauka i osvita. 7/ CXVII,7-12 [in Ukrainian].

9. Sannikova, O.P. \& Hordiienko, I.O. (2018) Psykhodiahnostychna metodyka «Indyvidualna kompozytsiia pokaznykiv samopryiniattia»: perevirka teoretychnoho konstruktu [Psychodiagnostic technique «Individual composition of self-acceptance indicators»: verification of theoretical construct]. Problemy suchasnoi psykholohii: zb. nauk. prats Derzhavnoho vyshchoho navchalnoho zakladu "Zaporizkyi natsionalnyi universytet» ta Instytutu psykholohii imeni H. S. Kostiuka NAPN Ukrainy. 1(13), 140-146 [in Ukrainian].

10. Sannikova, O.P. \& Hordiienko, I.O. (2019). A.s. Naukovo-metodychnyi tvir «Kompleks metodyk diahnostyky yakisnykh komponentiv samopryiniattia: «Ekspres-diahnostyka yakisnykh komponentiv samopryiniattia»; «Indyvidualna kompozytsiia yakisnykh pokaznykiv samopryiniattia»»» [Copyright certificate. Scientific-methodical essay «Complex methods of diagnostics of self-acceptance qualitative components:«Express-diagnostics of self-acceptance qualitative components»; «Individual composition of self-acceptance qualitative indicatorsı»»)] Reiestrats. № 93758 vid 07.11.2019 [in Ukrainian].

11. Fromm, E. (2007). Iskusstvo ljubit' [The art of loving]. Sankt-Peterburg: ID "Azbukaklassika» [in Russian].

12. Chepelieva, N.V. (2013). Metody analizu opovidalnoho tekstu [Methods of narrative text analysis]. Tekhnolohii rozvytku intelektu. 4, 4. http://nbuv.gov.ua/j-pdf/tri 2013 4_4.pdf [in Ukrainian].

13. Herbert, J.D., Forman, E.M., \& England, E.L. (2009). Psychological acceptance. - General Principles and Empirically Supported Techniques of Cognitive Behavior Therapy / edited by William O'Donohue, Jane Fisher. (pp. 102-114)

URL:https://www.researchgate.net/publication/230745911_Psychological_acceptance 
14. Williams, J.C., \& Lynn, S.J. (2010) Acceptance: an historical and conceptual review. Imagination, cognition and personality, 30 (1), 5-56. https://doi.org/10.2190/IC.30.1.c

\title{
THE PHENOMENON OF SELF-ACCEPTANCE AND ITS MANIFESTATION: CONTENT-ANALYSIS OF SELF-REPORTS IN THE FORM OF ESSAYS Iryna Hordiienko
}

Postgraduate student of the Department of General and Differential Psychology

South Ukrainian National Pedagogical Ushynskyi University

26, Staroportofrankivska Str., Odesa, Ukraine, 65020

2sanak@gmail.com, https://orcid.org/0000-0001-7089-2698

\begin{abstract}
The article presents the research results of a wide range of self-acceptance phenomenon manifestations as a multilevel personality trait, which reflects the person degree and specificity of self-being acceptance. The aim is to discover the qualitative characteristics of self-acceptance, which represents modality (quality and sign - acceptance or non-acceptance) and characteristics in the context of the basic types of the person mental activity: emotional, cognitive and behavioral. The theoretical basis of the research: the continuum-hierarchical concept of personality structure by O. Sannikova, which represents the self-acceptance qualitative characteristics. The main research method: content analysis of self-reports. The subject of the study is the indicators of self-acceptance qualitative characteristics. The content-analysis procedure of self-reports in the form of essays by the theme «Self-acceptance and its manifestations» was carried out in three stages: preparatory, executive and analyticalinterpretative. The analysis identified 274 linguistic units that provide additional information about the psychological content and structure of the personality self-acceptance phenomenon. Thesauruses of self-acceptance qualitative indicators were compiled into the corresponding blocks. The emotional block includes the emotionally experience characteristics of personality existence recognition. Indicators of the self-acceptance cognitive parameter present a continuum of traits that reflect a person's consent to being as they are, in the mind. Behavioral parameter indicators reflect the acceptance or non-acceptance behavioral manifestations. The controlregulatory indicators reflect the degree of control emotional, cognitive, behavioral selfrepresentations and a degree of self-awareness at an individually accepted level. Content analysis has identified personality traits that are hypothetically related to self-acceptance, and selfacceptance factors.
\end{abstract}

Keywords: self-acceptance, structure of self-acceptance, self-reports in the form of essays, content-analysis, qualitative characteristics of self-acceptance.

Подано 11.02.2020

Рекомендовано до друку 19.02.2020 